\title{
Comparison of different cryoprotective agents on swamp buffalo semen cryopreservation
}

\author{
M.T. Herbowo ${ }^{1,2}$, R.I. Arifiantini ${ }^{3}{ }^{3}$, , N.W.K .Karja ${ }^{3}$ and R.G. Sianturi ${ }^{4}$ \\ ${ }^{1}$ Biology of Reproduction, Post Graduate School of IPB University, \\ Jl. Agatis Raya, Dramaga Campus, Bogor 16680 - Indonesia \\ ${ }^{2}$ Permanent Address: Singosari National Artificial Insemination Centre (SNAIC), \\ Malang, East Java 65153 - Indonesia \\ ${ }^{3}$ Division of Reproduction and Obstetrics, Department of Veterinary Clinic, \\ Reproduction and Pathology, Faculty of Veterinary Medicine, IPB University, \\ Jl Agatis Raya, Dramaga Campus, Bogor 16680 - Indonesia \\ ${ }^{4}$ Indonesian Research Institute for Animal Production, \\ Jl Raya Tapos No.36, Banjar Waru, Ciawi, Bogor, 16720 - Indonesia \\ *Corresponding E-mail: Arifiantini@apps.ipb.ac.id
}

Received March 26, 2020; Accepted June 17, 2020

\begin{abstract}
ABSTRAK
Penelitian ini bertujuan menguji efektivitas berbagai konsentrasi gliserol dan dimetilformamida (DMF) sebagai krioprotektan alternatif dalam pengencer Tris-Kuning Telur (TEY) terhadap kualitas semen beku kerbau lumpur. Semen segar dengan motilitas $>60 \%$ dibagi dalam 8 tabung berisi pengencer mengandung gliserol dan DMF masing-masing 4, 5, 6, 7\%. Semen cair yang telah diencerkan, dikemas ke dalam straw $(0,25 \mathrm{~mL})$, diekuilibrasi pada suhu $4{ }^{\circ} \mathrm{C}$ selama 4 jam, dibekukan dalam uap nitrogen cair (8 cm dari permukaan nitrogen cair) selama 10 menit dan disimpan dalam kontainer nitrogen cair dengan suhu $-196{ }^{\circ} \mathrm{C}$. Straw setelah 24 jam disimpan, di-thawing dengan air hangat $\left(37^{\circ} \mathrm{C}\right)$ selama 30 detik. Hasil menunjukkan motilitas sperma setelah ekuilibrasi hampir sama untuk semua konsentrasi gliserol. Motilitas sperma paling rendah pada pengencer dengan konsentrasi DMF 7\% $(\mathrm{P}<0,05)$. Motilitas sperma setelah pembekuan dan recovery rate terbaik diperoleh pada pengencer dengan konsentrasi gliserol 7\% dan DMF 5\% dibandingkan dengan konsentrasi lain $(\mathrm{P}<0,05)$. Viabilitas dan keutuhan membran plasma sperma dalam pengencer yang mengandung gliserol $6 \%$ atau $7 \%$ lebih tinggi $(\mathrm{P}<0,05)$ daripada yang mengandung gliserol $4 \%$ atau $5 \%$. Viabilitas dan keutuhan membran plasma sperma dalam pengencer mengandung 5\% DMF lebih tinggi $(\mathrm{P}<0,05)$ daripada yang mengandung 4\%, 6\% dan 7\% DMF. Kesimpulan dari penelitian ini adalah 5\% DMF atau 7\% gliserol dapat digunakan dalam pembekuan semen kerbau lumpur dengan hasil yang sama baiknya.
\end{abstract}

Kata kunci : dimetilformamida, gliserol, kerbau lumpur, krioprotektan, sperma

\begin{abstract}
Present study aimed to determine the effectiveness of dimethylformamide (DMF) as cryoprotective agent (CPA) by determining its optimum concentration in Tris Eggyolk (TEY) extender on the quality of post-thaw swamp buffalo semen. Only ejaculates having $>60 \%$ sperm motility were divided into eight $s$ tubes. Four tubes were diluted in TEY with 4, 5, 6, 7\% of glycerol and four other tubes were diluted in TEY with $4,5,6,7 \%$ of DMF. Diluted semen then packed into ministraw $(0.25 \mathrm{~mL})$, equilibrated at $4{ }^{\circ} \mathrm{C}$ for 4 hours and freezed at $8 \mathrm{~cm}$ above liquid nitrogen vapour for 10 minutes and then stored at liquid
\end{abstract}


nitrogen container. After 24 hours of storage, straws were thawed at $37{ }^{\circ} \mathrm{C}$ for 30 seconds. The result showed that sperm motility after equilibration tend to be the same at all four glycerol concentrations, whereas the decrease in motility was highest in extenders with a DMF concentration of $7 \%(\mathrm{P}<0.05)$. Post-thaw sperm motility and recovery rate in TEY extender containing 5\% DMF or 7\% glycerol were highest $(\mathrm{P}<0.05)$ than other glycerol or DMF concentration. Sperm viability and membrane integrity did not differ among TEY containing $6 \%$ or $7 \%$ glycerol, both were higher $(\mathrm{P}<0.05)$ than $4 \%$ or $5 \%$ glycerol. Viability and membrane integrity of sperm in $5 \%$ DMF was superior $(\mathrm{P}<0.05)$ to $4 \%, 6 \%$ or $7 \%$. This research concluded that $5 \%$ DMF or $7 \%$ glycerol was considered to be the most suitable CPAs for swamp buffalo semen cryopreservation.

Keywords: cryoprotectant, dimethylformamide, glycerol, sperm, swamp buffalo

\section{INTRODUCTION}

Buffalo (Bubalus bubalis) is one of the alternative livestock commodities which is a potential source of animal protein in Indonesia. Based on Central Statistics Agency data from 2004 to 2015 , there was a decline in the buffalo population of more than one million head (BPS, 2015). One effort that can be done to increase buffalo population in Indonesia is to optimize the application of reproductive technology. Artificial insemination (AI) is a reproductive technology that has proven to be effective and can be widely applied in the field (Singh and Balhara, 2016). One of the success factors of the AI program is the quality of the frozen semen. The quality of frozen semen according to Ariantie et al., (20130 is determined by freezing techniques, the type of diluent and the type and concentration of Cryoprotective agent (CPAs)

Many factors that cause the low quality of frozen semen include the type of semen, type and concentration of cryoprotectants, and the condition of the buffalo fresh semen. Semen consists of sperm and seminal plasm. Buffalo sperm are known to be more susceptible to the freezing process compared to bovine sperm because of the high content of phosphatidylcholine $(66 \%)$ and phosphatidylethanolamine (23\%), which make up the plasm membrane so that it is sensitive to cold shock (Andarabi, 2009).

Extender play an important role in maintaining the quality of sperm during freezing. Tris extender with the addition of egg yolk are widely used in the semen cryopreservation of various animal species since they were proven to maintain the quality of sperm (Dorado et al., 2007). Tris extenders are able to maintain $\mathrm{pH}$ stability, osmotic pressure and electrolyte balance and provide a source of energy for sperm.
Addition of glycerol to the extender could prevent the formation of ice crystals during freezing which is commonly used for cryopreservation of buffalo semen (Sansone et al., 2000).

Amide-based cryoprotectants since the 2000s began to be used as an alternative to glycerol because they are known to have low toxicity to sperm. Dimethylformamide (DMF) is one of the recommended amides and is often used in the freezing of mammalian semen in particular which has a high degree of sensitivity to freezing. The molecular weight of DMF (73.09 g/ mol) is lower than glycerol $(92.05 \mathrm{~g} / \mathrm{mol})$ therefore DMF has a higher permeability to penetrate the sperm membrane (Bezerra et al., 2011). The use of DMF in freezing process of horse semen have been widely used (Arifiantini and Supriatna, 2007), as well as in bovine (Oh et al., 2012) and buck semen (Ariantie et al., 2013).

Recently the quality of buffalo frozen semen is still low, efforts should be made to find cryoprotectant alternatives that are able to maintain the quality of buffalo semen during freezing. It is known that DMF has the ability to maintain the semen quality of various animals especially those that are prone to freezing. However, the effectiveness of DMF in buffalo semen freezing is still unknown. Therefore, this study was aimed to determine the effectiveness of using DMF as an alternative CPAs other than glycerol for swamp buffalo semen freezing in Tris-yolk extender.

\section{MATERIALS AND METHODES}

\section{Semen Source}

Fresh semen was obtained from two swamp buffalo belonging to Animal Research Institute Ciawi, Bogor (Balitnak). Both buffalo are aged 7 and 10 years old, respectively, in good health condition and reproductive period and had a good 
libido. Both buffalo were kept in individual cages. Fresh forage food was given as much as $10 \%$ of body weight with an additional concentrate of 4 kg every day.

\section{Extender Preparation}

The extender used was Tris-egg yolk(TEY). Buffer Tris consist of $3.03 \mathrm{~g}$ Tris hydroxymethil aminomethan, $1.70 \mathrm{~g}$ citric acid and $1.23 \mathrm{~g}$ of fructose dissolved in $100 \mathrm{~mL}$ aquabides. Buffer Tris was added by $20 \%$ egg yolk of the total volume. Into the buffer, $1000 \mathrm{IU} \mathrm{mL} \mathrm{mL}^{-1}$ of penicillin, and $1 \mathrm{mg} \mathrm{mL}^{-1}$ of streptomycin were added (Sukhato et al., 2001). Glycerol and DMF CPAs are given according to treatment (4-7\%).

\section{Semen Collection and Evaluation}

Fresh semen was collected in the morning using artificial vagina. Immediately after collection, the semen was brought to the laboratory for quality evaluation. Evaluation of the quality of fresh semen included macroscopic characteristics (volume, color, $\mathrm{pH}$, and consistency) and microscopy (mass movement, motility, concentration, viability, plasma membane integrity and sperm morphology). Evaluation of frozen semen included motility, recovery rate, viability, and plasm membrane integrity.

\section{Frozen semen Processing}

Semen which had a motility of more than
$60 \%$ with a concentration of more than $800 \times 10^{6}$ sperm $\mathrm{ml}^{-1}$ was divided into 8 tubes. The first four tubes were diluted with Tris Egg Yolk glycerol $4 \%$ (TEYG4), TEY with glycerol 5\% TEY (TEYG5), TEY with glycerol 6\% (TEYG6), andTEY with $7 \%$ glycerol (TEYG7). The other four tubes were diluted with TEY 4\% DMF (TEYD4), TEY 5\% DMF (TEYD5), TEY 6\% DMF (TEYD6), TEY 7\% DMF (TEYD7). The concentration of sperm in each tube was $100 \times 10^{6}$ cells $\mathrm{mL}^{-1}$. The semen was packed in $0.25 \mathrm{~mL}$ mini straw and equilibrated at $4{ }^{\circ} \mathrm{C}$ for 4 hours. Freezing was done by placing straw in liquid nitrogen vapor ( $8 \mathrm{~cm}$ above liquid nitrogen) using a styrofoam box for 10 minutes and then stored in liquid nitrogen containers $\left(-196{ }^{\circ} \mathrm{C}\right)$.

Evaluation of the frozen semen quality was done by thawing frozen semen in warm water $\left(37^{\circ} \mathrm{C}\right)$ for 30 seconds. Thawed semen was inserted into the microtube during evaluation was carried out. The collection and processing of semen was conducted individually, each repeated 4 times and the semen quality testing was carried out as many as 5 straw from each treatment $(n=32)$.

\section{Data Analysis}

Data were analyzed using Analysis of Variance (ANOVA) with further tests of DMRT (Steel and Torrie, 1960). The research data were presented in mean values with their respective standard error of mean (SEM).

Table 1. Semen Characteristics of Buffalo Bull

\begin{tabular}{lc}
\hline \multicolumn{1}{c}{ Parameter } & Average \pm SEM \\
\hline Macroscopic & \\
Volume (mL) & $2.34 \pm 0.11$ \\
Color & Milky white \\
Consistency & Thin to moderate \\
pH & 6.4 \\
Microscopic & \\
Mass movement & ++ \\
Sperm motility (\%) & $70.35 \pm 0.89$ \\
Sperm viability $(\%)$ & $83.21 \pm 0.65$ \\
Sperm intact membrane (\%) & $83.78 \pm 0.53$ \\
Sperm abnormality $(\%)$ & $15.34 \pm 0.53$ \\
Sperm concentration $\left(\mathrm{x} 10^{6} \mathrm{~mL}-1\right)$ & $1154 \pm 49.14$ \\
\hline
\end{tabular}




\section{RESULTS}

The characteristics of buffalo semen had a normal range and suitable for freezing (Table 1). The characteristics of fresh semen obtained are different for each collection. The average volume of ejaculate obtained was $2.34 \pm 0.11 \mathrm{~mL}$. The color, consistency and $\mathrm{pH}$ of the semen in this study tended to be stable. Buffalo semen in this study had a $\mathrm{pH}$ of 6.4 which was in accordance to the reports of Kaka et al. (2016) that the $\mathrm{pH}$ variation of buffalo semen is around 6.1 to 6.8 . Microscopic characteristics of fresh semen obtained in this study include mass movement (+ + ), sperm motility $(70.35 \pm 0.89 \%)$, sperm viability $(83.21 \pm 0.89 \%)$, plasma membrane integrity $(83.78 \pm 0.53 \%)$, sperm abnormalities $(15.34 \pm 0.53 \%)$ and sperm concentrations (1.154 \pm 60.76 million cells $\mathrm{mL}^{-1}$ ). All microscopic data shows a normal range (Table 1).

\section{Effects of Various Glycerol and Dimethylformamide (DMF) Concentrations on Sperm Motility in Tris-Yolk Diluents After Equilibration}

The observation of motility after equilibration showed that the motility of sperm tend to be the same at all four glycerol concentrations, whereas the decrease in motility was highest in extenders with a DMF concentration of $7 \%(\mathrm{P}<0.05)$ as shown in Table 2.

Effects of Various Glycerol and Dimethylformamide (DMF) Concentrations on Sperm Quality in Tris-Yolk Diluents After Freezing

The results of this study indicated that glycerol and DMF could be used as cryoprotectants to protect sperm from damage during freezing with different optimal concentrations. The optimal concentration of glycerol in Tris-yolk extenders was 7\% with sperm motility after freezing of $45.25 \pm 1.37 \%$, recovery rate of $64.27 \pm 1.91 \%$, viability of 68.41 $\pm 1.02 \%$ and plasm membrane intact $69.58 \pm$ $1.16 \%$ (Figure 1 - Figure 4). The optimal concentration of DMF obtained in this study was $5 \%$ with motility after freezing of $46.41 \pm 1.21 \%$, recovery rate of $65.95 \pm 1.70 \%$, sperm viability of $67.65 \pm 1.32 \%$ and plasm membrane integrity of $69.35 \pm 1.05 \%$.

\section{DISCUSSION}

The characteristics of fresh semen have had a normal range and are suitable for freezing (Table 1). The volume of swamp buffalo semen ranges from 1.9 to $3.4 \mathrm{~mL}$ (Koonjaenak et al., 2007 ) and the $\mathrm{pH}$ variation of buffalo semen is between 6.1 and 6.8 due to the metabolic activity of sperm which produce lactic acid (Kaka et al., 2016). The same characteristics are also reported in swamp buffalo in Thailand (Koonjaenak et al., 2007).

Semen quality decreased during freezing due to a series of processes that cause stress on sperm. In general the sperm motility is reduced after equilibration compared to fresh semen. A decrease in temperature causes cold shock which changes the structure and permeability of the plasm membrane (Siemme et al., 2015). Cold shock generally occurs at temperatures of $5-15^{\circ} \mathrm{C}$ (Drobnis et al., 2013). This leads to changes in membrane function, especially the membrane proteins structural changes, lead to the disruption of ion channel regulation, which in turn reduced cell function related to sperm motility, viability, and its fertility. A part from changes in the function of ion channels from membrane proteins, membrane leakage due to changes in the structure of the double layer to hexagonal also increases membrane permeability, which turn affects

Table 2. Swamp Buffalo Sperm Motility of Fresh and after Equilibration in Tris Egg Yolk Diluents with Various Concentrations of Glycerol and Dimethylformamide (DMF)

\begin{tabular}{lccccc}
\hline \multirow{2}{*}{ CPAs } & Fresh Semen & \multicolumn{4}{c}{ CPAs Concentration } \\
\cline { 3 - 6 } & & $4 \%$ & $5 \%$ & $6 \%$ & $7 \%$ \\
\hline Glycerol & $70.35 \pm 0.89 \mathrm{a}$ & $57.88 \pm 1.36 \mathrm{~b}$ & $59.00 \pm 1.65 \mathrm{~b}$ & $60.25 \pm 1.36 \mathrm{~b}$ & $59.63 \pm 1.41 \mathrm{~b}$ \\
DMF & $70.35 \pm 0.89 \mathrm{a}$ & $59.00 \pm 1.56 \mathrm{~b}$ & $58.38 \pm 1.49 \mathrm{~b}$ & $58.38 \pm 1.49 \mathrm{~b}$ & $53.00 \pm 1.32 \mathrm{c}$ \\
\hline
\end{tabular}

Different superscript at the same row indicate differences $(\mathrm{P}<0.05)$. CPAs $=$ Cryoprotective agent 


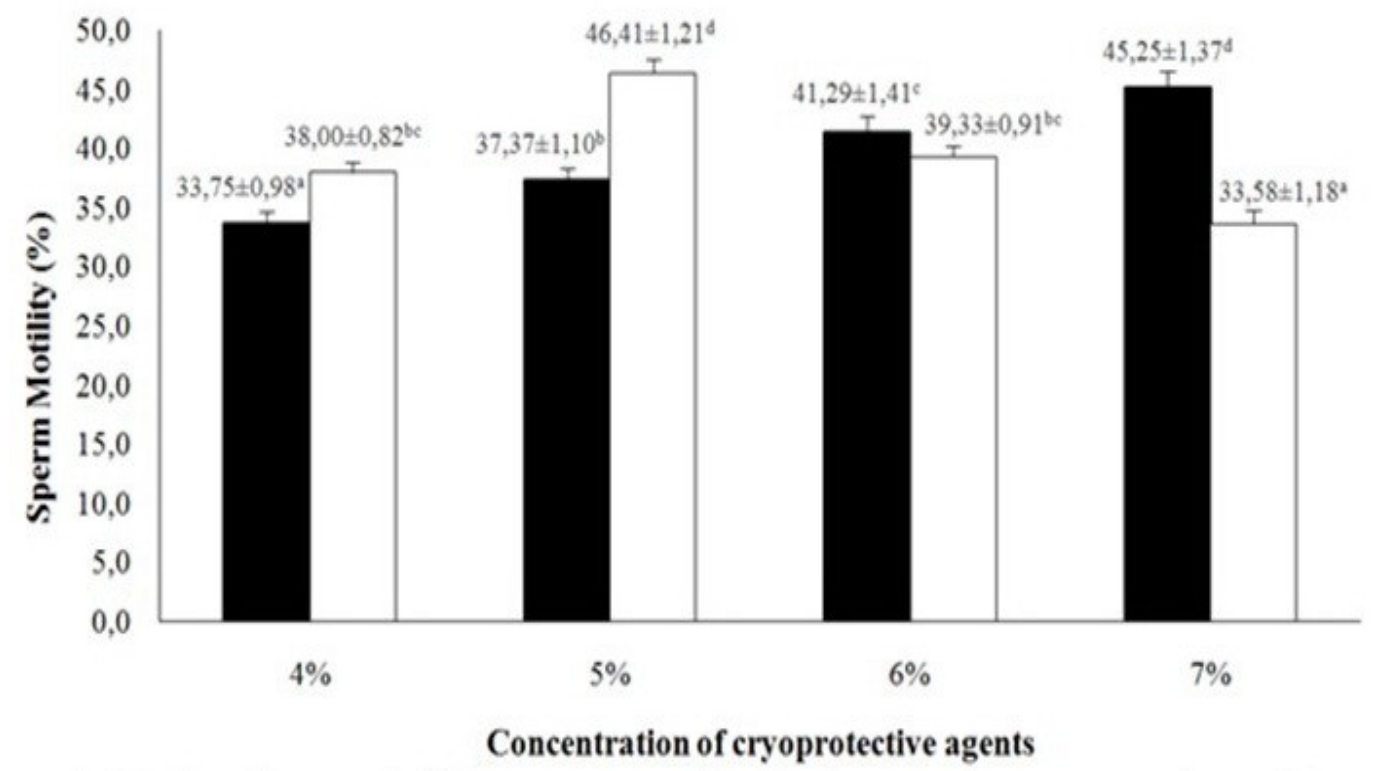

Figure 1. Motility of swamp buffalo sperm after freezing at various concentrations of glycerol ( $\mathbf{m})$ and DMF ( $\square$ ). The vertical lines above each data bar indicate standard errors and the superscript indicate the comparison of the mean motility values in each according to the DMRT test at the 0.05 level.

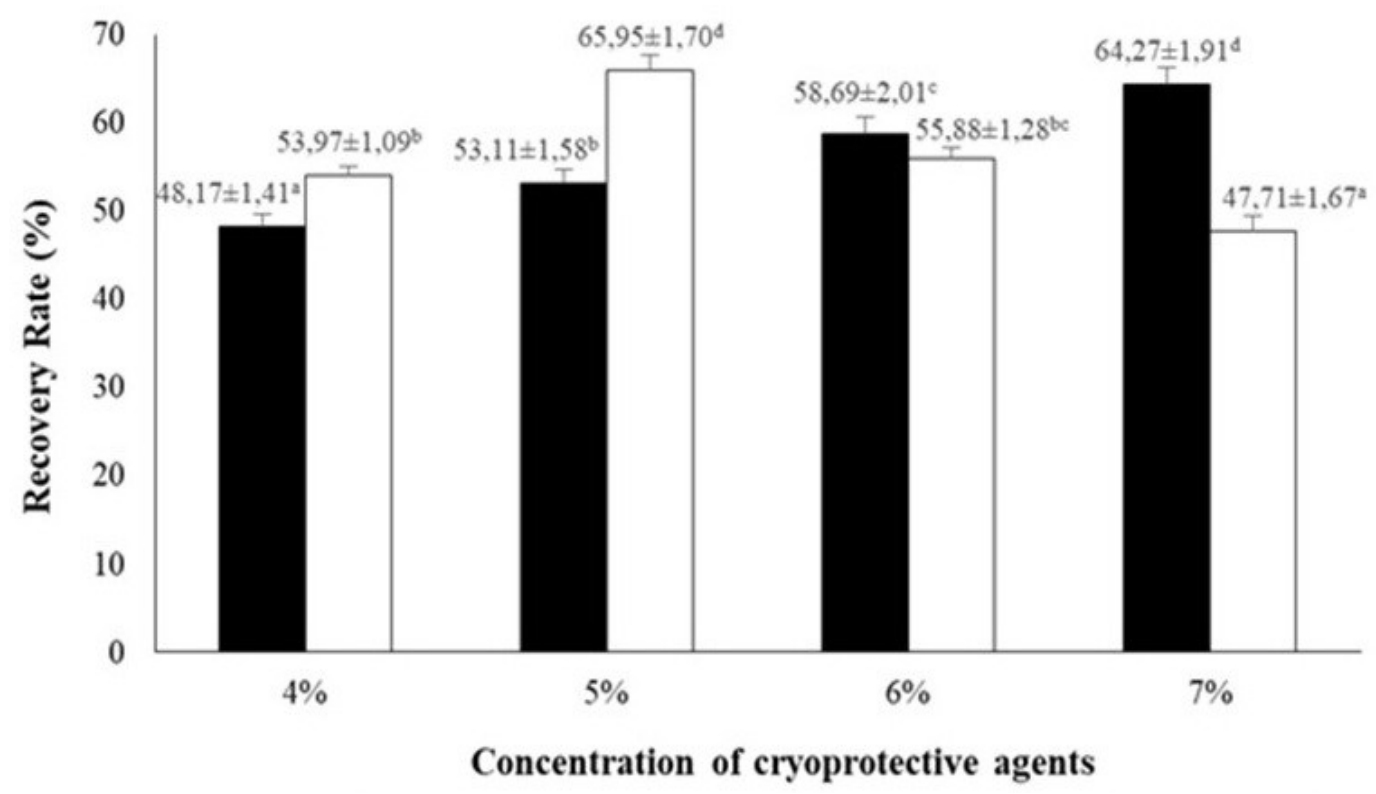

Figure 2. Recovery rate of swamp buffalo sperm after freezing at various concentrations of glycerol (ש) and DMF ( $\square$ ). The vertical line above each data beam shows the standard error and the superscript show the comparison of the recovery rate median for each treatment based on the DMRT test at a significant level of 0.05

intracellular activity.

Glycerol has a higher molecular weight than DMF and is thought to cause osmotic stress. In contrast, Fahy (1984) reported that osmotic stress factors did not significantly affect cell viability when exposed to hypertonic media. Shortening the duration of cell exposure to cryoprotectants can increase cell viability (Hunt, 2019). This 


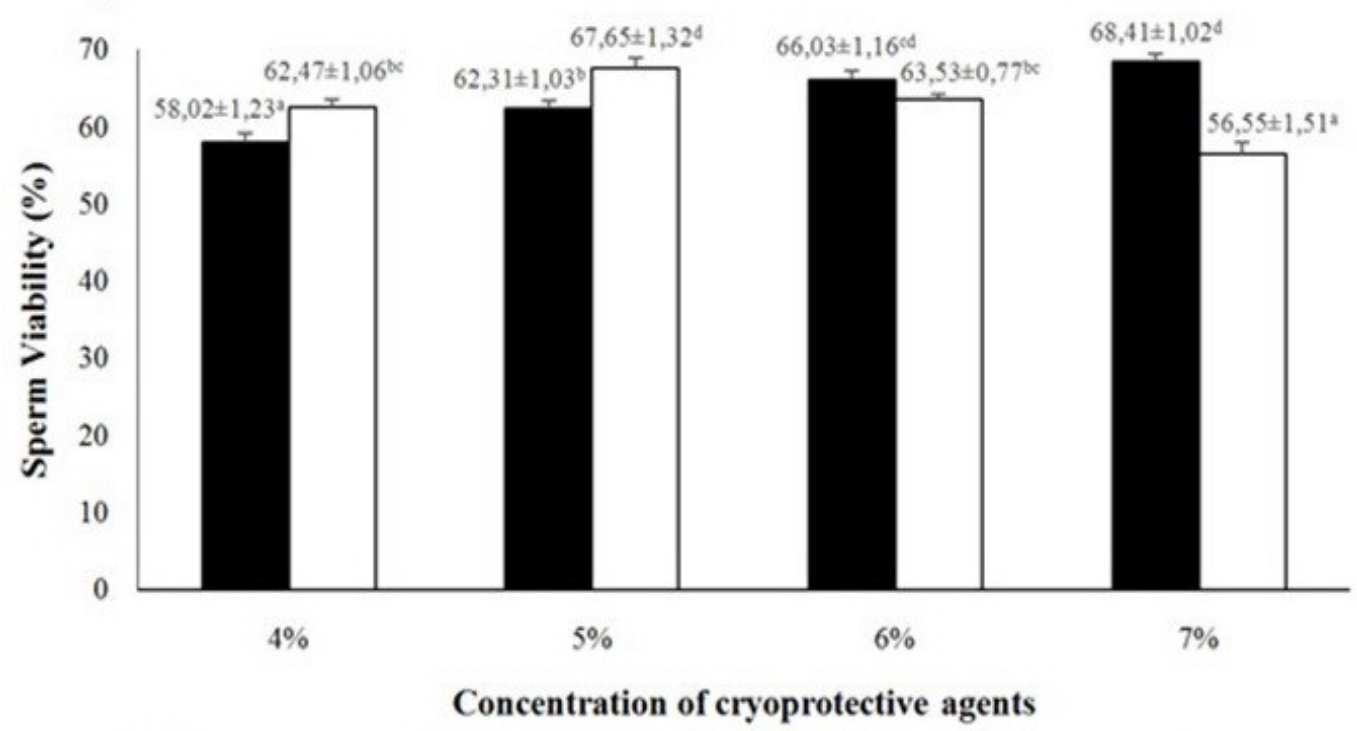

Figure 3. Viability of swamp buffalo spermat after freezing at various concentrations of glycerol (घ) and DMF ( $\square$ ). The vertical lines above each block of data indicate standard errors and the superscript show the comparison of the mean viability of each treatment based on the DMRT test at a significant level of 0.05

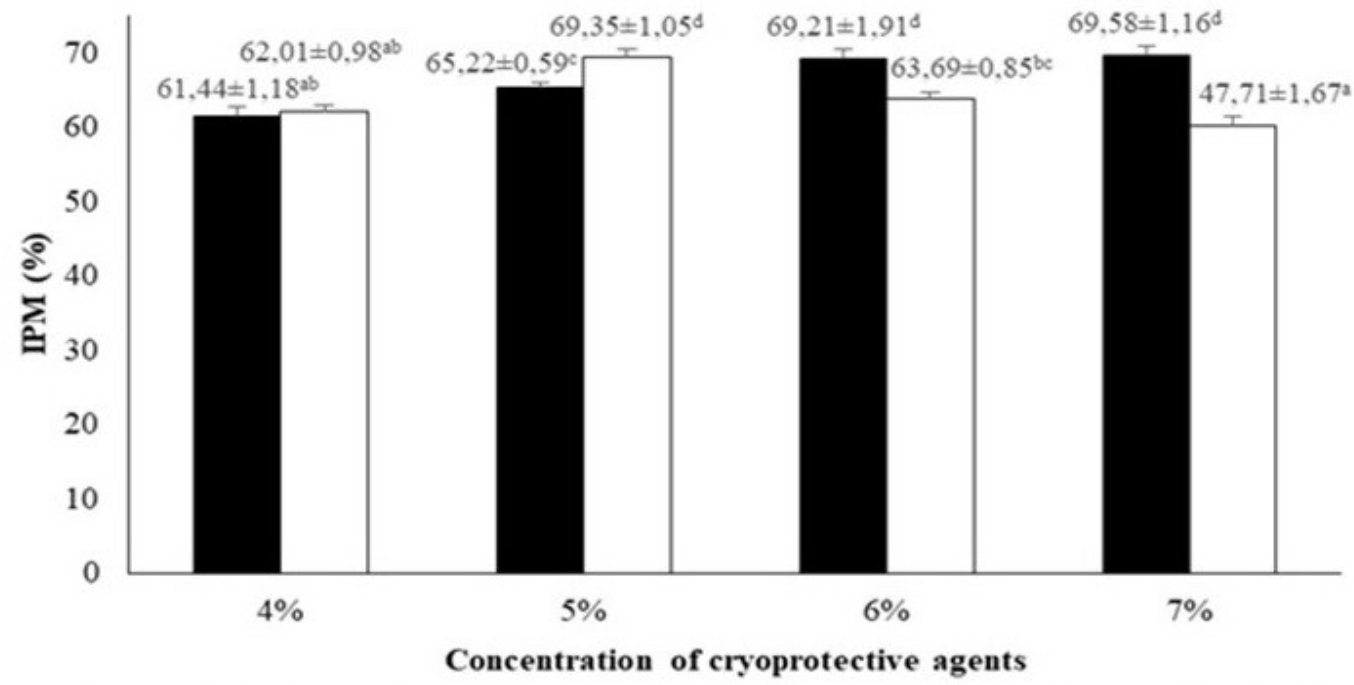

Figure 4. Intact plasma membrane (IPM) of swamp buffalo sperm after freezing at various concentrations of glycerol ( $\square$ ) and DMF ( $\square$ ). The vertical line above each data beam shows the standard error and the superscript show the comparison of the IPM mean value for each treatment based on on the DMRT test at a significant level of 0.05

proves that biochemical toxicity is a major factor causing cell damage rather than osmotic stress. The results of this study indicate that DMF has a stronger toxic effect than glycerol through biochemical mechanisms. Hantson et al. (2010) reported that DMF will be toxic if it has undergone structural changes to methyl isocyanate (MIC) which can reduce glutathione levels.

The decrease in glutathione levels is caused by MICs conjugated with cellular glutathione to 
form S- (N-methylcarbamoyl) gluthatione (SMG) and subsequently to form N-acetyl-S- (Nmethylcarbamoyl) cysteine (AMCC) which is also toxic to cells (Kim and Kim, 2011). Klug et al. (1998) reported that exposure to DMF caused abnormalities in mice embryos cultured in vitro. Zhang et al. (2015) reported that an increase in levels of the enzyme aspartate trans-aminase (AST) and alanine trans-aminase (ALT) in blood serum in tanneries workers who often inhale and are exposed to DMF.

Increased levels of AST and ALT indicate damage to the mitochondria that produce ATP. Sperm that suffer from membrane damage are known to release AST from the mitochondria so that ATP production is disrupted and sperm lose energy to move forward (Arifiantini and Purwantara, 2010). Table 2 shows the toxic effect of DMF was seen to be significant at $7 \%$ concentration after equilibration with the lowest motility of $53.00 \pm 2.98 \%$.

During freezing process, the formation of ice crystals begins with the nucleation process in the extracellular part. As the temperature decreases, the size of the ice crystals increases. Ice crystals that are formed are the accumulations of interlocking water molecules (Hunt, 2019). This causes the solute in the extracellular fluid to shift to the fraction that is still liquid, resulting in an increase in the concentration of the solute (Meryman, 2007). The high concentration of dissolved ions in extracellular fluid can damage the structure and stability of the plasma membrane or is called the solution effect. In addition, this hyperosmotic condition causes osmotic imbalance between intracellular and extracellular. Intracellular fluid will be pulled out causing cell shrinkage. If shrinkage occurs beyond the tolerance limit of cells, cells will be irreversibly damaged (Meryman, 2007).

Osmotic stress is a major limiting factor in the use of glycerol as a cryoprotectant (MaciasGarcia et al., 2012). Glycerol penetrates the cells slowly when the freezing process occurred, therefore glycerol couldn't replace the water that comes out from cell, leading to cell shrinkage. Conversely at the time of thawing, there the delay in glycerol coming out of the cell and extracellular fluid returns to the cell leading to cell swelling (Pegg, 2007). Mughal et al. (2013) reported that the osmotic pressure of buffalo semen was $289.4 \mathrm{mOsm} / \mathrm{kg}$ and diluent with osmotic pressure approaching that number showed the best quality.
Dimethylformamide has a better ability to penetrate cell membranes quickly because of its lower molecular weight than glycerol. Dimethylformamide as amides belong to the group of penetrating cryoprotectants, which act by means of their colligative properties, decreasing the intracellular freezing point. This will minimize the occurrence of osmotic stress. Its presence in the diluent also reduces the concentration of sodium so that the solution effect can be avoided (Meryman, 2007). However, its use is limited because of its toxic nature which will occur through biochemical mechanisms.

Dimethylformamide is widely used as a cryoprotectant agent because of its good ability to penetrate cell membranes. In addition DMF is easily dissolved in water and has a good ability to bind to other molecules so as to prevent the collection of water molecules that cause ice crystals to form. Low molecular weight causes DMF to have a good ability to penetrate cells quickly so that it can minimize the occurrence of osmotic stress (Bezerra et al., 2011). However, DMF at certain levels also known to have toxic effects.

Dimethylformamide undergoes oxidation by the CYP2E1 enzyme during the freezing process into N-methylformamide (NMF) and free radicals. Free radicals that are formed will adversely affect cells and can trigger changes in mitochondrial DNA associated with sperm motility (Shieh et al., 2007). This is exacerbated by the oxidation of NMF to MIC which will conjugate with cellular glutathione to AMCC which is also considered a DMF metabolite that is toxic through oxidative stress mechanisms that cause mitochondrial damage (Kim and Kim, 2011). Mitochondrial dysfunction causes inhibition of ATP production so that sperm motility is impaired. Oxidative stress caused by free radicals also inflict damage to the plasm membrane (Gazali and Tambing, 2002), which indicated by sperm absorbing a lot of color when tested for its viability and not responding to the hypotonic solutions.

In this study glycerol and amides can protect sperm cells during cryopreservation, their cryoprotectant properties are achieved by different mechanisms. Glycerol is an alcohol that contains three functional hydroxyl groups, which can accept one hydrogen from the water molecule in six different binding sites (Dalimata et al., 1997). Dimethil Formamine as amides are formed by functional groups that contain nitrogen $(\mathrm{NH}-$ $\mathrm{C}=\mathrm{O}$ ). Dimethil Formamine interact with the 
water by binding their nitrogen and hydrogen content to the hydrogen present in the water molecule.

The lower molecular weight and viscosity in comparison to glycerol, DMF have higher membrane permeability, decreasing the possibility of cellular damage caused by osmotic stress (Watson, 2000). Therefore, the CPAs effect of amides can be attributed to their ability to permeate the cell membrane due to their low molecular weights, which likely allows them to bind to water molecules more efficiently than glycerol (Watson 2000; Holt 2000).

The parameters measured in this study include motility, recovery rate, viability, and plasm membrane integrity. All four parameters tend to show the same pattern. Figures 1 to 4 show that glycerol with a concentration of $7 \%$ in Tris-egg yolk diluents is able to maintain the quality of buffalo swamp sperm. The use of DMF as cryoprotectant is also able to maintain the quality of buffalo sperms at a concentration of $5 \%$.

Cryoprotectant concentrations in protecting sperm is varying. Concentration of 4,5 and $6 \%$ glycerol and $4 \%$ of DMF in this study were not able to protect buffalo sperm during freezing. While 6 and 7\% DMF might be toxic. Cryoprotectants can be toxic in different ways, but there are apparently common features of toxicity which correlate with the capacity of substances to cryoprotect.

\section{CONCLUSION}

Based on the results of the study concluded that glycerol and DMF can protect buffalo swamp sperm well during freezing. Glycerol with a concentration of $7 \%$ or $5 \%$ DMF in Tris-egg yolk diluents can equally protect buffalo sperm during freezing. Thus as suggestion for freezing sperm buffalo in Tris Egg yolk extender can be use 7\% glycerol or $5 \%$ of DMF as CPAs.

\section{ACKNOWLEDGEMENTS}

The authors acknowledge the Indonesian Endowment Fund for Education, Indonesian Ministry of Finance contract number PRJ2451/LPDP/2015 for providing the funding. Heartfelt thanks to Ms Nia, Ms Yanti and all staffs at Large Ruminant Unit Indonesian Research Institute for Animal Production for their valuable technical support.

\section{REFERENCES}

Andarabi, S.H.M. 2009. Factors affecting the quality of cryopreserved buffalo (Bubalus bubalis) bull sperm. Reprod in Dom Anim. 44(9):552-569.

Ariantie, O.S., T.L. Yusuf, D. Sajuthi and R. I. Arifiantini. 2013. Pengaruh krioprotektan gliserol dan dimethilformamida dalam pembekuan semen kambing peranakan etawah menggunakan pengencer Tris modifikasi. J. Ilmu Ternak Vet. 18(4):239250.

Arifiantini, R.I. and B. Purwantara. 2010. Motility and viability of Friesian Holstein sperm in three different extender stored at $5{ }^{\circ} \mathrm{C}$. J. Indonesian Trop. Anim. Agric. 35(4):222226.

Arifiantini, R.I. and I. Supriatna. 2007. Kriopreservasi semen kuda menggunakan berbagai krioprotektan pada pengencer susu skim. J. Ilmu Ternak Vet. 12(2):139-146.

Badan Pusat Statistik [BPS]. 2015. Populasi kerbau menurut provinsi 2000-2015. https://www.bps.go.id/Subjek/view/id/24\#su bjekViewTab3. Downloaded May 15, 2016.

Badan Standardisasi Nasional [BSN]. Semen Beku Kerbau. SNI 4869.2:2008.

Bezerra, F.S.B., T.S. Castelo, H.M. Alves, I.R.S. Oliveira, G.L. Lima, G.C.X Peixoto, A.C.S.D Bezerra and A.R Silva. 2011. Objective assessment of the cryoprotective effects of dimethylformamide for freezing of goat semen. Cryobiololy. 63(3):263-266.

Dalimata, A.M, and J.K Graham. 1997. Cryopreservation of rabbit spermatozoa using acetamide in combination with trehalose and methylcellulose. Theriogenology. 49 (5):831-41

Dorado, J., I. Rodriguez and M. Hidalgo. 2007. Cryopreservation of goat spermatozoa: Comparison of two freezing extenders based on post-thaw sperm quality and fertility rates after artificial insemination. Theriogenology. 68(2):168-177.

Drobnis, E.Z, L.M. Crowe, T. Berger, T.J. Anchordoguy, W. Overstreet and J.J.H. Crowe. 1993. Cold shock damage is due to lipid phase transition in cell membranes: a demonstration using sperm as a model. J. Exp. Zool. 265:432-437.

Fahy, G.M. 1984. Cryoprotectant toxicity: biochemical or osmotic? Cryo Lett. 5:79-90. 
Gazali, M. and S.N. Tambing. 2002. Kriopreservasi sel spermatozoa: ulasan. Hayati. 9 (1): 27-32.

Hantson, P., A. Villa, A.C. Galloy, S. Negri, G. Esabon, F. Lambiotte, V. Haufroid and R. Garnier. 2010. Dimethylformamide metabolism following self-harm using a veterinary euthanasia product. J. Clin. Toxicol. 48(7):725-729

Holt, W.V. 2000. Basic aspects of frozen storage of semen. Anim. Reprod Sci. 62:3-22.

Hunt, C.J. 2019. Technical Considerations in the Freezing, Low-Temperature Storage and Thawing of Stem Cells for Cellular Therapies. Transfus Med Hemother 46:134149

Kaka, A., A.A. Memo, P. Khatri, H.K. Kumbhar, D.H. Kalhoro, M. Tariq, S.A Pirzado and A.N. Tunio. 2016. Determination of quality characteristics of Khundi buffalo bull semen. Int. J. Basic App. Sci. 12:394-397.

Karow, A.M. 2001. Cryobiology 2001 for mammalian embryologists. Georgia, USA: Augusta; 2001. p.1-37.

Kim, T.H. and S.G. Kim. 2011. Clinical outcomes of occupational exposure to $N, N$ dimethylformamide: perspectives from experimental toxicology. Saf Health Work. 2(2):97-104.

Klug, S., H.J. Merker and R. Jackh. 1998. Potency of monomethyl-, dimethylformamide and some of their metabolites to induce abnormal development in a limb bud organ culture. Toxicol. In Vitro. 12(2):123-132.

Koonjaenak, S., V. Chanatinart, S. Aiumlamai, T. Pinyopumimintr and $\mathrm{H}$. RodriguezMartinez. 2007. Seosonal variation in semen quality of swamp buffalo (Bubalus bubalis) in Thailand. Asian J. Androl. 9(1):92-101.

Macias-Garcia, B., F.C. Ortega, I.M. Aparicio, A. Miro-Moran, R.A. Morillo, B.J.M. Gallardo, F.L. Gonzalez, C.M. Balao da Silva, H. Rodrıguez-Martınez, J.A. Tapia and F.J. Pena. 2012. Toxicity of glycerol for the stallion spermatozoa: effects on membrane integrity and cytoskeleton, lipid peroxidation and mitochondrial membrane potential. Theriogenology. 77(7):12801289.

Meryman, H.T. 2007. Cryopreservation of living cells: principles and practice. Transfusion.
47(5):935-945

Mughal, D.H., A. Ijaz, M.S. Yousaf, H. Rehman, M. Aleem, H. Zaneb and F. Wadood. 2013 Assessment of optional osmotic pressure of citrate egg yolk extender for cryopreservation of buffalo bull (Bubalus bubalis) semen. J. Anim. Plant Sci.23(4):964-968.

Oh, S.A., S.H. Choi, M.H. Ko, T.Y. Kang, S.R. Cho, M.S. Ko, Y.M. Oh and W.M. Cho. 2012. Effect of amides as a cryoprotectant on quality of frozen-thawed sperm in korean jeju black bull. J. Anim. Sci. Technol 54(2):95-101.

Pegg, D.E. 2007. Principles of cryopreservation. In: Day JG, Stacey GN, (eds). Cryopreservation and Freeze-Drying Protocols 2nd Ed. Humana Press. New Jersey.

Sansone, G., M.J.F. Nastri and A. Fabbrocini. 2000. Storage of buffalo (Bubalus bubalis) semen. Anim. Reprod. Sci. 62(1-3):55-76.

Shieh, D.B., C.C. Chen, T.S. Shih, H.M. Tai, Y.H. Wei and H.Y. Chang. 2007. Mitochondrial DNA alteration in blood of the human exposed to N,N-dimethylformamide. Chem. Biol. Interact. 165(3):211-219.

Singh, I and A.K. Balhara. 2016. New approaches in buffalo artificial insemination programs with special reference to India. Theriogenology. 86(1):1-6.

Steel, R.G.D and J.H. Torrie. 1960. Principles and Procedures of Statistics. (With special Reference to the Biological Sciences.) McGraw-Hill Book Company, New York, Toronto, London

Sukhato, P., S. Thongsodseang, A. Utha and N. Songsasen. 2001. Effects of cooling and warming conditions on post-thawed motility and fertility of cryopreserved buffalo spermatozoa. Anim. Reprod. Sci. 67(12):69-77.

Watson, P.F. 2000. The causes of reduced fertility with cryopreserved semen. Anim. Reprod. Sci. 60:481-92

Zhang, H., Q. Liu, Y. Duan, H. Dong and Y. Zhou. 2015. Chronic occupational $\mathrm{N}, \mathrm{N}$ dimethylformamide poisoning induced death: a case report. Forensic Sci. Med. Pathol. 11(4):584-588. 